\title{
Toxic Effects of Levafix Blue CA and Levafix Amber CA Reactive Dyes on Liver and Kidney in Mice
}

\author{
Mohammad Farhadur Rahman ${ }^{1}$, Nargish Jahan Ara ${ }^{1}$, Mohammad Mesbah Uddin ${ }^{2}$, \\ Mohammad Zakir Sultan ${ }^{3}$ \\ ${ }^{1}$ Department of Chemistry, Bangladesh University of Textiles, Dhaka, Bangladesh \\ ${ }^{2}$ Department of Clinical Pathology, Dhaka Medical College, Dhaka, Bangladesh \\ ${ }^{3}$ Centre for Advanced Research in Sciences, University of Dhaka, Dhaka, Bangladesh
}

Email address:

zakir.sultan@du.ac.bd (M. Z. Sultan), chemistry.butex2010@gmail.com (M. Z. Sultan)

\section{To cite this article:}

Mohammad Farhadur Rahman, Nargish Jahan Ara, Mohammad Mesbah Uddin, Mohammad Zakir Sultan. Toxic Effects of Levafix Blue CA and Levafix Amber CA Reactive Dyes on Liver and Kidney in Mice. International Journal of Nutrition and Food Sciences. Vol. 6, No. 5, 2017 pp. 187-193. doi: 10.11648/j.ijnfs.20170605.11

Received: June 18, 2017; Accepted: July 5, 2017; Published: July 31, 2017

\begin{abstract}
The healthy life of human depends on healthy foods as well as food safety. But unethical practice of textile dyes as adulterant damages the safety of food chain. Textile industries also uses textile dyes to full-fill increase demand of textile products, which produce large waste dye as effluent in ground water due to inefficiency of dying process and causes serious environmental pollution. In this study, we investigated the toxic effects of two textile reactive dyes Levafix Blue CA and Levafix Amber CA by in vivo experiments in mice. Mice were administered Levafix Blue CA and Levafix Amber CA textile dyes at a single oral dose of $0.04 \mathrm{~g} / \mathrm{kg}$ daily for 21 days to observe any toxic effect of those dyes in mice. The toxic effects were evaluated by measuring the serum activity of aspartate amino-transferase (AST), glutamate pyruvate transaminase (ALT), serum total bilirubin (STBI), serum creatinine (SCR), serum urea (SBUN) and also histopathology of liver and kidney. The levels of AST, ALT, STBI, SBUN and SCR were found to be increased by both Levafix Blue CA and Levafix Amber CA. Histopathological examination of liver and kidney revealed inflammation in mice.
\end{abstract}

Keywords: In Vivo, Reactive Dyes, Levafix Blue CA, Levafix Amber CA, Toxicity

\section{Introduction}

Food adulteration is a national issue. It began a couple of decades ago and this practice is increasing day by day. The problem of adulteration persists at every level of foods from preparation to consumption. Textile dyes use as coloring agents instead of food grades colorant due to cheapness of textile dyes. Consumption of adulterated food items severely affects the human health by producing many acute and chronic diseases. [1]

In various kinds of sweets and fast-foods like jilapi (local name of a sweetmeat), piaju (local name of one kind of fast food), chop, beguni (local name of one kind of fast food) textile dyes used in indiscriminate manner in Bangladesh. [2] A report by the 'Poribesh Bachao Andolan' disclosed that about 7.9 million (79 lakh) people in South Asia die every year by non-contagious diseases, and food adulteration is marked as one of the most important reasons. The report also warned if this food adulteration cannot be prevented now, it will affect the mental growth in next generation. [1, 3]

The supply of unsafe foods is negatively contributing to the public health seriously with numerous acute and chronic diseases. Yet, little work on the toxicity was published before. [4]

A study in Dhaka city in 2003 found that $96 \%$ of sweetmeats, $24 \%$ of biscuits, $54 \%$ of bread and $59 \%$ of icecreams were seriously adulterated by poisonous chemicals. [5] Use of poisonous chemicals in perishable foods is endangering the lives of people. [6]

Moreover, the textile industry consumes a substantial amount of water in its manufacturing processes used mainly in the dyeing and finishing operations of the plants. The wastewater from textile plants is classified as the most polluting of all the industrial sectors, considering the volume 
generated as well as the effluent composition. [7], [8] It is estimated that over 10,000 different dyes and pigments are used industrially. [9] In the textile industry, up to 200,000 tons of these dyes are lost to effluents every year during the dyeing and finishing operations, due to the inefficiency of the dyeing process. [10] Unfortunately, most of these dyes escape conventional wastewater treatment processes and persist in the environment as a result of their high stability to light, temperature, water, detergents, chemicals, soap and other parameters such as bleach and perspiration. [11] In addition, anti-microbial agents resistant to biological degradation are frequently used in the manufacture of textiles, particularly for natural fibers such as cotton. [11, 12]

It has been reported that during the dyeing process $10 \%$ of the dye stuffs used remain unfixed from the fibers. [13] Another report published that up to $30 \%$ of the used dyestuff remains in the spent dye-bath after the process due to inefficiency of dying process. [14]

The unused dyes in the effluent mix with water of river, pond or ground, and leading to serious environmental pollution which may ultimately serious health hazard. [7] In river, pond or ground water fishes are administered those textile dyes and we are taking those fishes as one of the main item of daily foods. Many dyes are carcinogenic and affect the life of aquatic organisms. [15] Olukanni et al. (2005) reported that the serious environmental problems for rapid growth of textile industry leads to harmful causes of agriculture issues, rise of heavy metals in ground water, drastic effects on flora and fauna in the surrounding area. [16]

Therefore, to evaluate the impact of textile dyes on human health, we conducted toxicity studies of some textile dyes in mice model. This paper describes the effects of the two textile dyes on the activity of some organs (liver and kidney) of mice.

\section{Materials and Methods}

\subsection{Materials} CA

Dye used: (a). Levafix Blue CA and (b). Levafix Amber

Levafix Blue CA and Levafix Amber CA are reactive dye, widely used in textile industry. Both reactive dyes were supplied by Dye Star Ltd., Dhaka, Bangladesh.

\subsection{Instruments}

Aspartate aminotransferase (AST) [AST formerly was called serum glutamic oxaloacetic transaminase (SGOT)], alanine aminotransferase (ALT) [ALT used to be called serum glutamic-pyruvic transaminase, or SGPT], serum urea and serum creatinine were determined by biochemical auto analyzer (Dimension Xpand Plus, Siemens, Germany). Histopathological observations were carried out under a light microscope (Olympus BX 53, Olympus, Japan).

\subsection{Experimentations}

Nine adult male mice, weighing 40-50 mg, were used in this experiment. All the rats were acclimatized to the new environment for a period of one week. During the experiment period the rats were kept in a well ventilated animal house at $25^{\circ} \mathrm{C}$. They were supplied with standard pellets and fresh drinking water. All the rats were kept in cage and maintained with natural $12 \mathrm{~h}$ light and dark cycle in the animal house of Institute of Nutrition and Food Sciences (INFS), University of Dhaka, Bangladesh. The mice were divided into three groups consisted of three mice each.

Group A and Group B were administered Levafix Blue CA dye and Levafix Amber CA, respectively at a single oral dose of $0.04 \mathrm{~g} / \mathrm{kg}$ daily (half dose of Mahmoud N. H.) for 21 days to observe any toxic effect of those dyes in mice. [17] 100.0 $\mathrm{mL}$ solution for both dyes was prepared at $0.04 \mathrm{~g} / \mathrm{kg}$ concentration. For each mouse oral dose was administered twice per day at $0.5 \mathrm{~mL} /$ time for 21 days besides normal foods. Group C was left as control and administered normal foods.

\subsection{Histopathological Examinations}

At the end of the experiment the control and treated mice were sacrificed. Their livers and kidneys were removed and fixed in $10 \%$ formalin solution, processed and embedded in paraffin wax. Sections of 3-6 $\mu \mathrm{m}$ thickness were stained with hematoxylin and eosin.

\subsection{Biochemical Analysis}

By decapitation of each mouse, blood was collected in centrifuge tube and kept 1 hour at room temperature for coagulation. Then centrifuged at $4000 \mathrm{rpm}$ for 20 minutes and serum was separated by decantation and placed at $-20^{\circ} \mathrm{C}$ until biochemical analyses were done.

AST and ALT were measured according to Wroblewski and LaDue [18] (recommended by IFCC as described by Bergmeyer [19, 20]). Serum TBI and serum urea were measured by the method of Doumas [21] (modification of diazo method described by Jendrassik and Grof [22]). Measurment of serum creatinine was determined by Larsen. [23]

\section{Results}

\subsection{Histopathological Results}

\subsubsection{Liver}

An unremarkable change was observed in liver of control mice (Figure 1 and 2). After treating with Levafix Blue CA reactive dye a mild inflammation of liver was observed in two mice (No. 1 and 3) but there was no significant effect on third one (No. 2) (Figure 3 and 4, respectively). Figure 5 shows unremarkable changes in liver which was obtained from Group B, mice No. 1 treated with Levafix Amber CA reactive dye but Figure 6 revealed mild inflammations of livers of mice No. 2 and 3 for the induced effect of the same dye. 


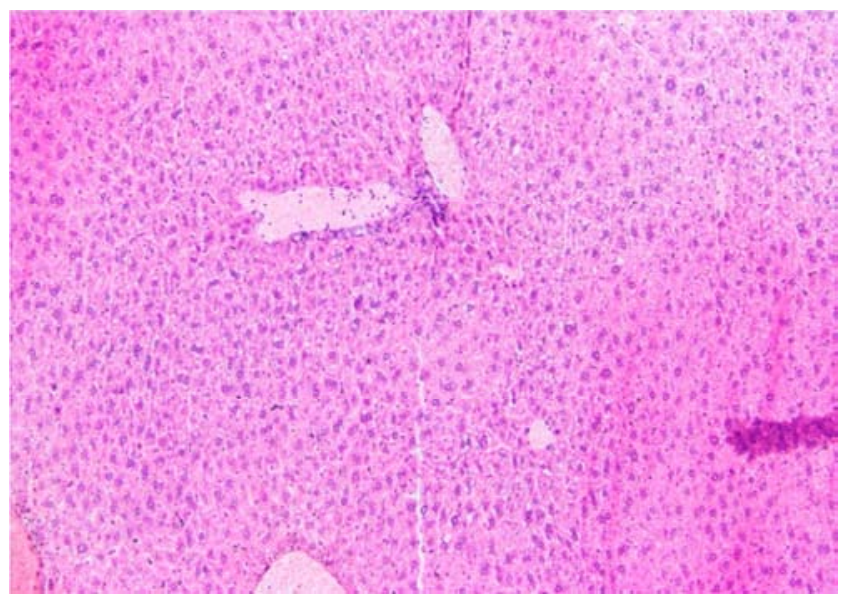

Figure 1. Liver section of control $1^{\text {st }}$ mice showing unremarkable liver tissue $(100 X)$.

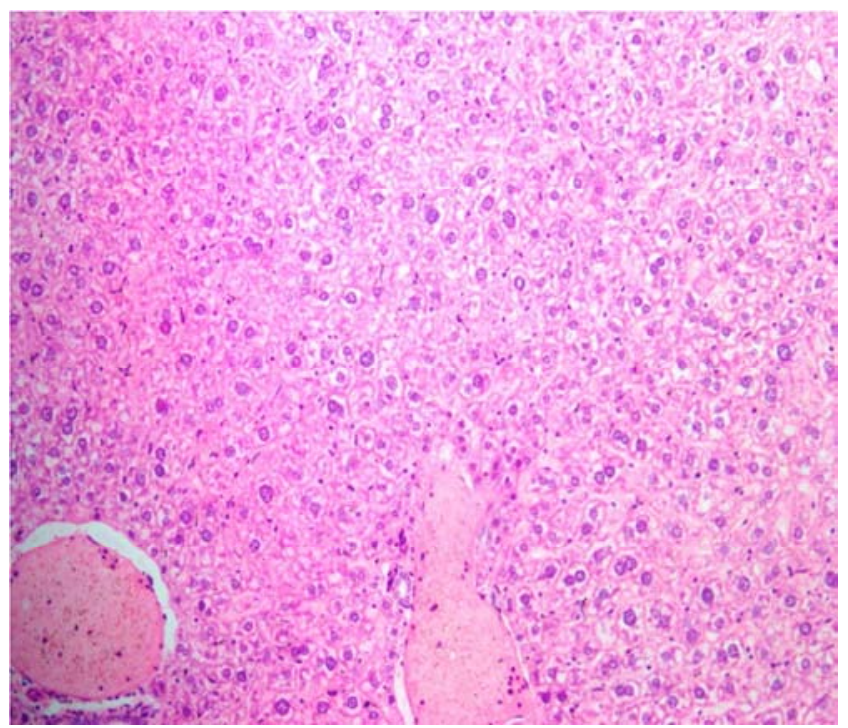

Figure 2. Liver section of control $2^{\text {nd }}$ mice showing unremarkable liver tissue $(200 X)$.

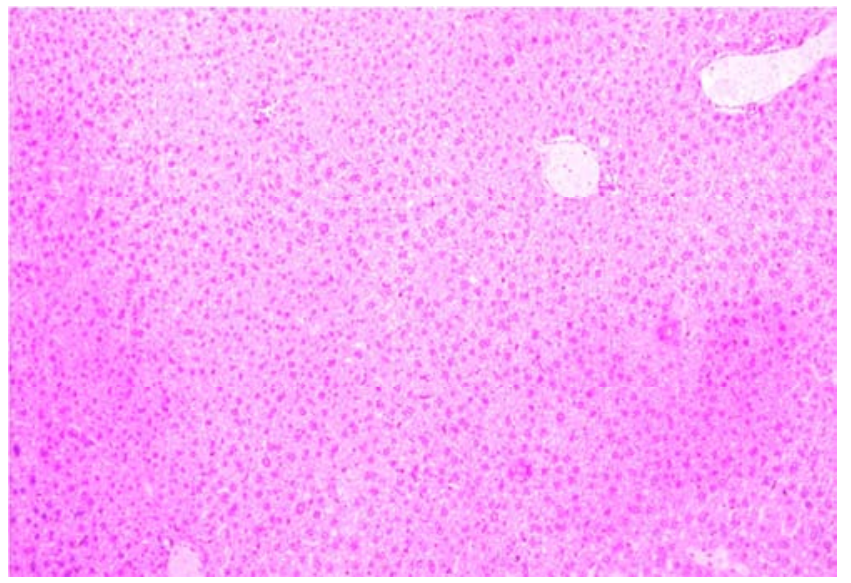

Figure 3. Liver section of Levafix Blue CA groups $1^{\text {st }}$ mice showing unremarkable liver tissue $(100 \mathrm{X})$.

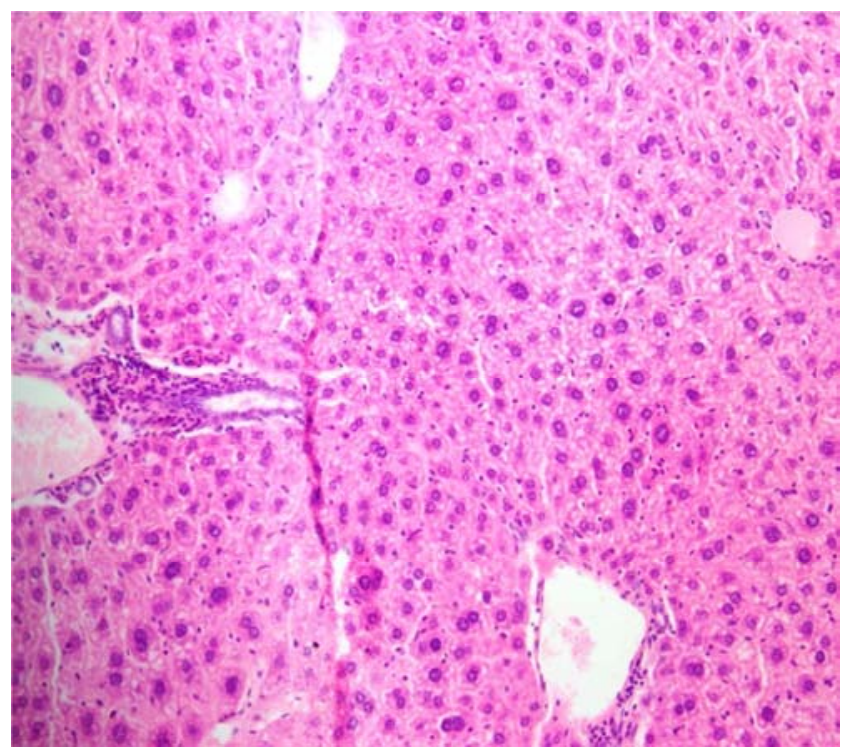

Figure 4. Liver section of Levafix Blue CA groups $2^{\text {nd }}$ mice showing mild inflammation of liver tissue $(200 \mathrm{X})$.

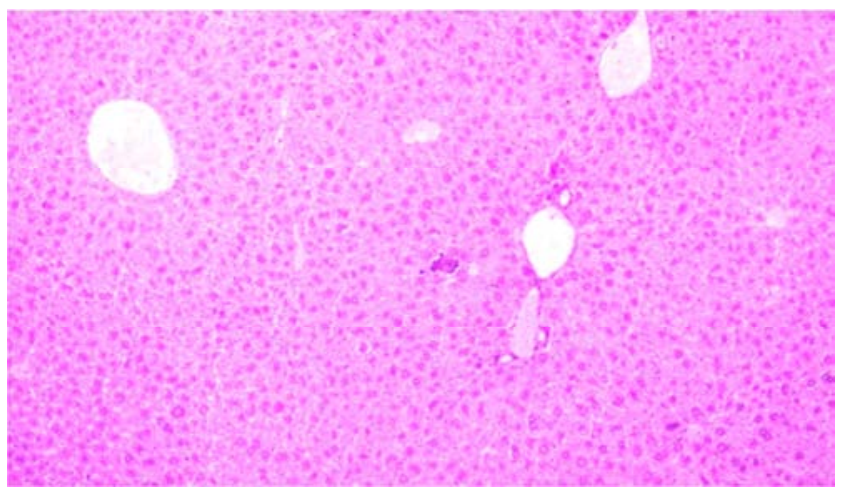

Figure 5. Liver section of Levafix Amber CA groups $1^{\text {st }}$ mice showing unremarkable liver tissue $(100 \mathrm{X})$.

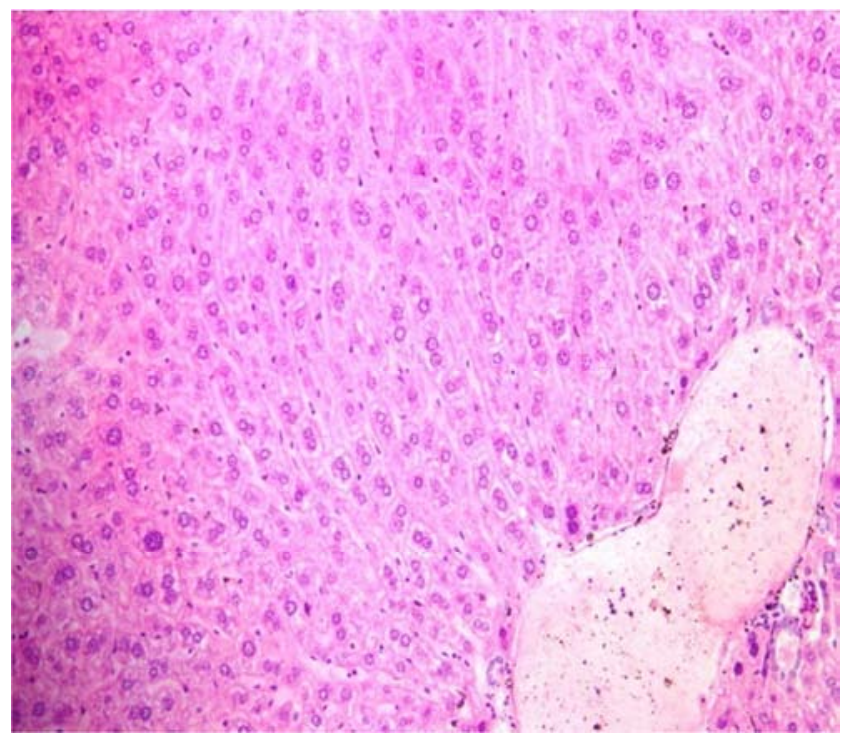

Figure 6. Liver section of Levafix Amber CA groups $2^{\text {nd }}$ mice showing mild inflammation of liver tissue $(200 \mathrm{X})$. 


\subsubsection{Kidney}

An unremarkable change showed in kidney for control mice (Figure $7 \&$ Figure 8). The observation for Group A after treating Levafix Blue CA reactive dye showed moderate inflammations in kidney of first and third mice (Figure 9). But for same dye there was mild inflammation in kidney of second mouse (Figure 10). A mild inflammation was observed in kidney in mouse No. 1 and 2 showed in Figure 12 for Group B after administered Levafix Amber CA reactive dye but unremarkable changes showed in Figure 11 for mouse No. 3 in kidney for same dye.

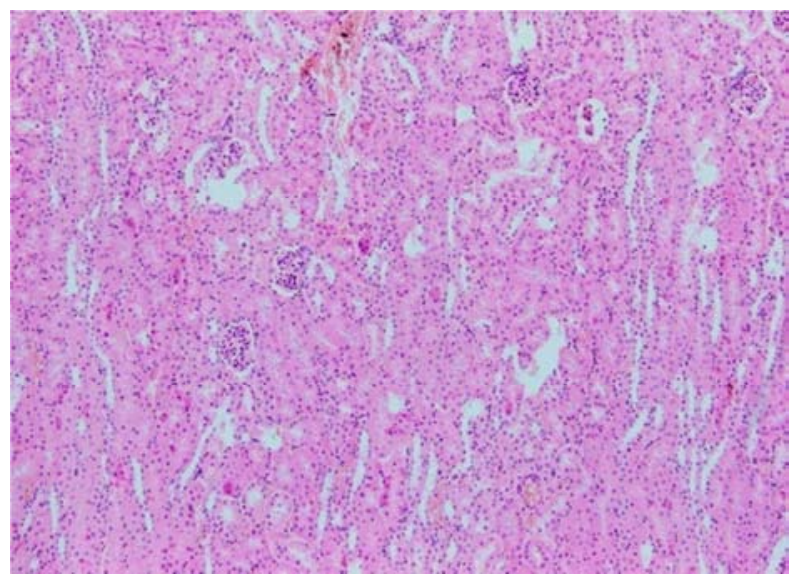

Figure 7. Section in kidney of $1^{\text {st }}$ control mice showing unremarkable kidney tissue $(100 \mathrm{X})$.

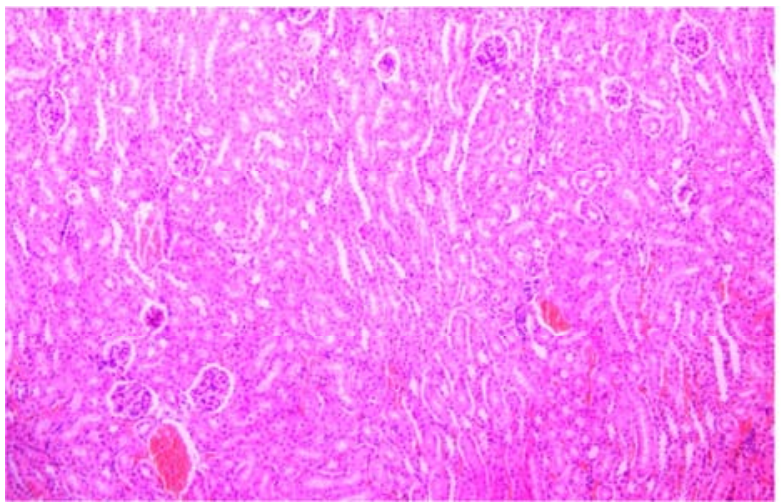

Figure 8. Section in kidney of $2^{\text {nd }}$ control mice showing unremarkable kidney tissue $(100 \mathrm{X})$.

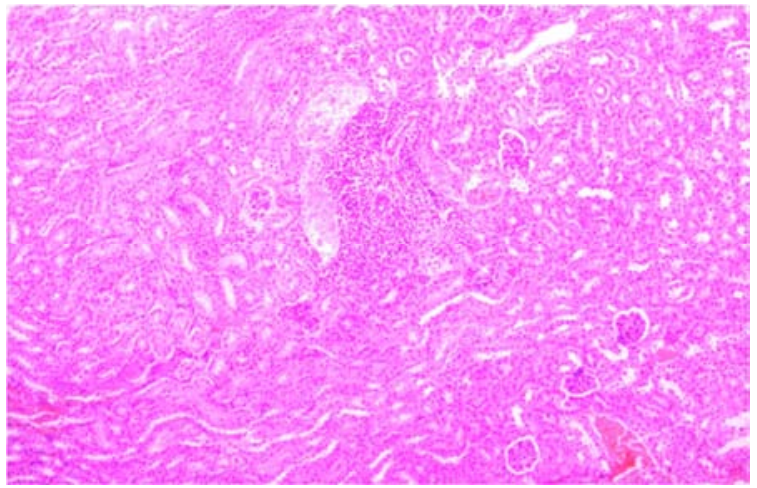

Figure 9. Section in kidney of Levafix Blue CA groups $1^{\text {st }}$ mice showing moderate inflammation kidney tissue $(100 \mathrm{X})$.

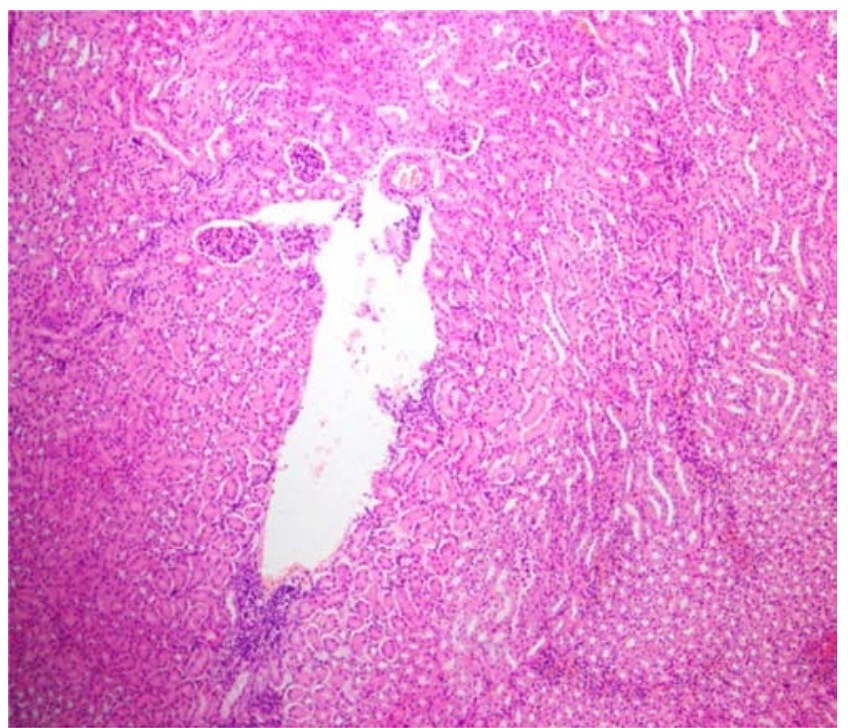

Figure 10. Section in kidney of Levafix Blue CA groups $2^{\text {nd }}$ mice showing mild inflammation kidney tissue (100X).

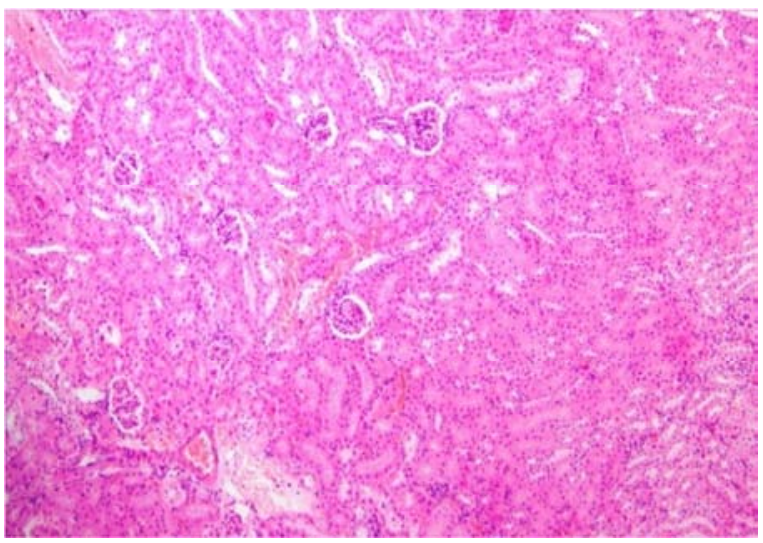

Figure 11. Section in kidney of Levafix Amber CA groups $1^{\text {st }}$ mice showing unremarkable kidney tissue $(100 \mathrm{X})$.

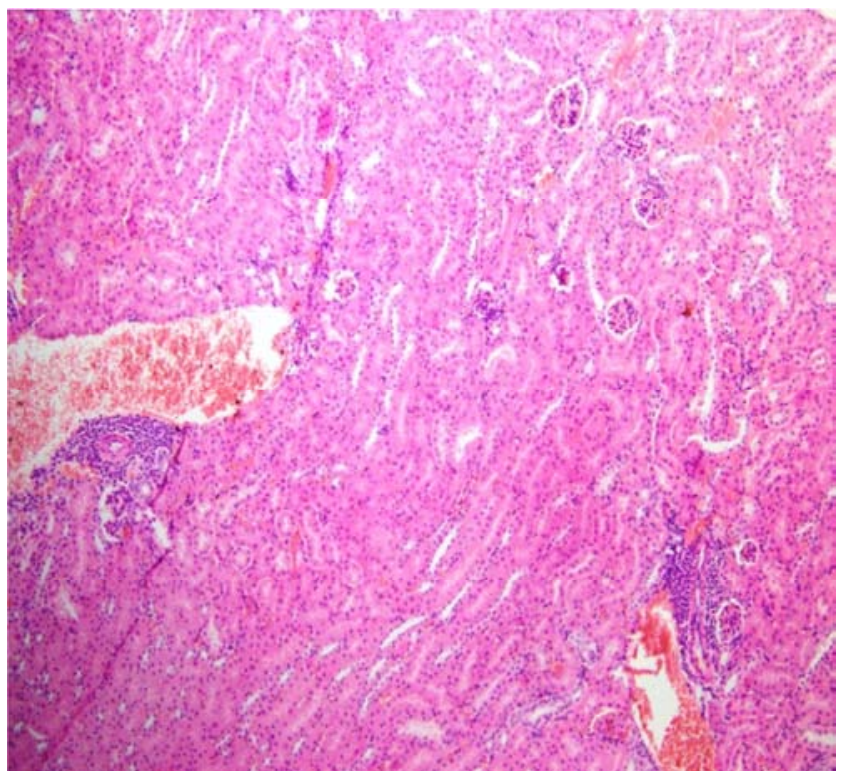

Figure 12. Section in kidney of Levafix Amber CA groups $2^{\text {nd }}$ mice showing mild inflammation kidney tissue $(100 \mathrm{X})$. 


\subsection{Biochemical Results (Serum Activity)}

\subsubsection{Liver Function Study}

Table 1 shows AST, ALT and TBI level of serum obtained from Group A (Levafix Blue CA), Group B (Levafix Amber
CA) and Group C (control). The values of AST, ALT and TBI level were changed significantly after the administration of Levafix Blue CA and Levafix Amber CA reactive dyes (Figure 13).

Table 1. Effects of Lever reactive textile dye on serum activity in liver function in male mice.

\begin{tabular}{|c|c|c|c|c|c|c|}
\hline \multirow{2}{*}{ Parameters } & \multicolumn{2}{|l|}{$\operatorname{AST}(\mu / \mathrm{dL})$} & \multicolumn{2}{|l|}{$\operatorname{ALT}(\mu / d L)$} & \multicolumn{2}{|c|}{ TBI (mg/dL) } \\
\hline & Individual & Average & Individual & Average & Individual & Average \\
\hline \multirow{3}{*}{ Control } & 85.0 & \multirow{3}{*}{89.3} & 20.0 & \multirow{3}{*}{19.7} & 0.50 & \multirow{3}{*}{0.40} \\
\hline & 96.0 & & 18.0 & & 0.30 & \\
\hline & 87.0 & & 21.0 & & & \\
\hline \multirow{3}{*}{ Levafix Blue CA } & 155.0 & \multirow{3}{*}{178.3} & 30.0 & \multirow{3}{*}{36.7} & 0.50 & \multirow{3}{*}{0.50} \\
\hline & 225.0 & & 45.0 & & 0.50 & \\
\hline & 155.0 & & 35.0 & & & \\
\hline \multirow[t]{2}{*}{ Levafix Amber CA } & 130.0 & \multirow[t]{2}{*}{230.0} & 15.0 & \multirow[t]{2}{*}{36.7} & 0.50 & \multirow[t]{2}{*}{0.50} \\
\hline & 135.0 & & 35.0 & & & \\
\hline
\end{tabular}

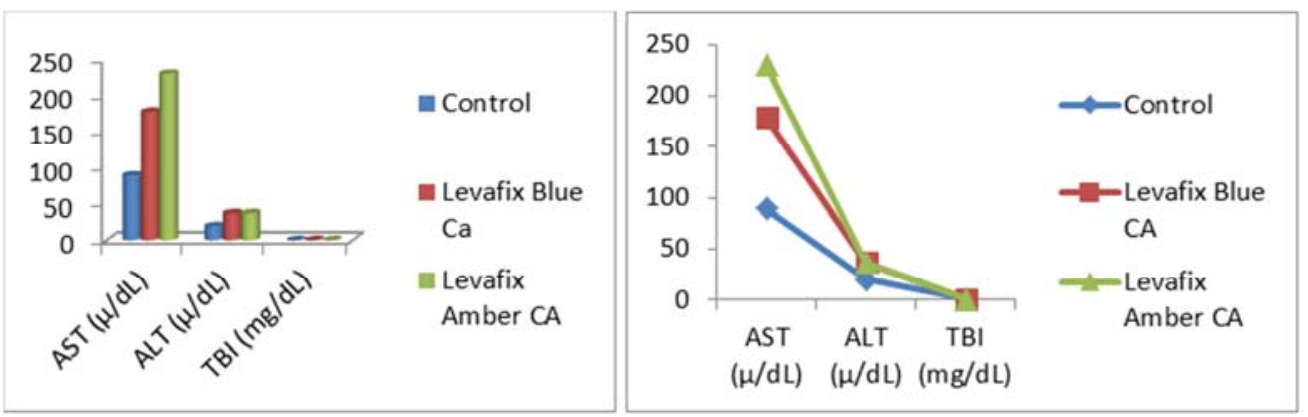

Figure 13. Comparison the effect of textile dyes on serum activity of liver function in male mice.

\subsubsection{Kidney Function Study}

Table 2 shows creatinine and SBUN level of serum obtained from Group A (Levafix Blue CA), Group B (Levafix Amber CA) and Group C (control). The values of creatinine and SBUN level were changed less significantly after the administration of Levafix Blue CA and Levafix Amber CA dyes (Figure 14).

Table 2. Effects of reactive textile dye on serum activity on kidney function in male mice.

\begin{tabular}{lllll}
\hline \multirow{2}{*}{ Parameters } & \multicolumn{2}{l}{ Creatinine $(\mathbf{m g} / \mathbf{d L})$} & \multicolumn{2}{l}{ SBUN $(\mathbf{m g} / \mathbf{d L})$} \\
\cline { 2 - 5 } & Individual & Average & Individual & Average \\
\hline \multirow{2}{*}{ Control } & 0.15 & & 10.0 & \\
& 0.24 & 0.14 & 6.0 & 8.3 \\
Levafix Blue & 0.03 & & 9.0 & \\
CA & 0.25 & & 15.0 & \\
& 0.25 & 0.22 & 10.0 & 11.7 \\
Levafix Amber & 0.60 & & 10.0 & \\
CA & 0.40 & 0.45 & 25.0 & 18.3 \\
& 0.35 & & 20.0 & \\
\hline
\end{tabular}

\subsection{Discussion}

Textile dyes represent a large group of organic compounds that could have undesirable effects on the environment, and in addition, some of them can pose risks to humans. The increased demand for textile products and the proportional increase in their production, and the use of textile dyes have together contributed to dye wastewater becoming one of the substantial sources of severe pollution problems in current times. Besides, consumption of adulterated food items severely affects the human health by producing many acute and chronic diseases.

This study was measuring the toxic effect of daily supply foods adulterated with textile dyes. To observe any effects of textile dyes mice were administeredLevafix Blue CA and Levafix Amber CA daily at oral dose of $0.04 \mathrm{~g} / \mathrm{kg}$ for 21 days.

Results obtained in the present work indicated that treating mice with Levafix Blue CA and Levafix Amber CA caused significant increase of AST, ALT levels in mice serum. Previous study suggested that damaged organs showed increase in enzyme activity and chronic intoxication was accompanied by continuous increase in serum levels in both AST and ALT activities. [17] It seems that the changes of AST and ALT activities are due to cellular degradation by Coralene Red XF and Remazol Red RR.

Treating mice with Levafix Blue CA and Levafix Amber CA induced less significant increase in serum TBI which may be due to the defect in liver function produced from hepato cellular damage. [24]

This study also found less significant changes in serum creatinine and serum urea for administering Levafix Blue CA reactive dye. But treating with Levafix Amber CA reactive dye showed significant increase in serum creatinine and serum urea. Mackenzie et al. (1992) found that the significant elevation in creatinine and urea levels related to impairment of renal or post renal function. [25] 
Histopathological examination of both liver and kidney revealed inflammation on mice and some times unremarkable after treating with Levafix Blue CA and Levafix Amber CA. Levafix Blue CA reactive dye showed moderate changs in kidney but mild inflammation in liver and some cases unchanged in liver. Levafix Amber CA reactive dye showed mild inflammation in both liver and kidney. There was also an unremarkable changes of liver and kidney for this dye. The unremarkable change might be due to the body immunity of mice. The protection capability varies mouse to mouse. The duration of study time also needs to extend for more accurate observation.

Through this work, the changes on serum activity of blood and histopathological impact on liver and kidney for textile dyes show the alarming about textile dyes for human health. Study at cellular and molecular level with this dye is necessary to get more insight about mechanism of impacts on liver and kidney. The increasing complexity and difficulty in treating textile wastes has led to a constant search for new methods that are effective and economically viable.

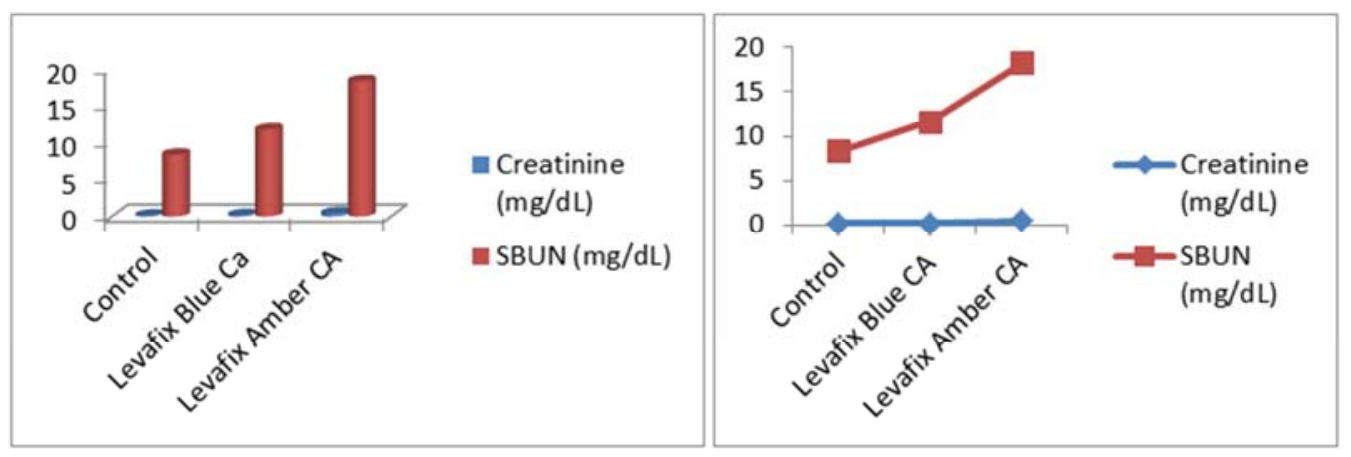

Figure 14. Comparison the effect of textile dyes on serum activity of kidney function in male mice.

\section{Conclusion}

Many people add textile dyes in foods to increase attraction or careless use of these dyes makes environmental pollution. From our study it was obviously found that the textile dyes are not safe for health. There are profound impacts on blood, liver and kidneys. The results of this study will aware people for not to use textile dyes in food. It will also aware the people working in textile industries for careful handling the dyes to prevent environmental pollution or food contamination.

\section{Acknowledgement}

The authors would to thanks Md. Bayejid Hosen, Divisional Forensic DNA Screening Laboratory, Khulna, Bangladesh and Bishnu Pada Dey, Department of Pathology, Bangladesh Sheikh Mujib Medical University, Bangladesh, for kind cooperation during research work. The authors also pay special thanks to Syeda Saba-E-Zannat, Mymensing Agriculture University, Bangladesh, for helping throughout the research period.

\section{References}

[1] Rahman, MA, Sultan MZ, Rahman MS, and Rashid MA. Food Adulteration: A Serious Public Health Concern in Bangladesh. Bangladesh Pharm J. 2014; 18(1): 1-7.

[2] Bahari ifterer somahar. The Daily Amader Somoy, (A daily newspaper of Bangladesh), 1 July 2014.

[3] Enforce existing laws against food adulteration. The Daily Observer. 22 June 2014.
[4] Borzelleca JF and Hallogen JB. Life time toxicity/Carcinogenicity Study of FD \& C Red No. 3 in mice. J FD Chem Toxicol. 1987; 25: 735.

[5] Rahman SM, Hoque MA and Talukder MRA. Food security in Bangladesh: utilization, nutrition and food adulteration (paper presented at the National Workshop on Food security, Dhaka, Bangladesh, 19-20 October 2005), 2005; pp. 45-46.

[6] Derek, L. Eight toxic foods: a little chemical education. In The Pipeline. 21 June, 2013.

[7] Przystas W, Zablocka-Godlewska E, Grabinska-Sota E. Biological Removal of Azo and Triphenylmethane Dyes and Toxicity of Process By-Products. Water Air Soil Pollut. 2012; 223 (4): 1581-1592.

[8] Sen S, Demirer GN. Anaerobic treatment of real textile wastewater with a fluidized bed reactor. Water Research. 2003; 37 (8): 1868-1878.

[9] Zollinger, H. Synthesis, Properties of Organic Dyes and Pigments. In: Color Chemistry. New York, USA: VCH Publishers. 1987; p. 92-102.

[10] Ogubue CJ, Sawidis T. Bioremediation and Detoxification of Synthetic Wastewater containing Triarylmethane Dyes by Aeromonas hydrophila Isolated from Industrial Effluent. Biotechnology Research International. 2011; DOI $10.4061 / 2011 / 967925$.

[11] Couto SR. Dye removal by immobolosed fungi. Biotechnology Advances. 2009; 27 (3): 221-235.

[12] O'Neill C, Hawkes FR, Hawkes DL, Lourenco ND, Pinheiro HM, Delee W. Colour in textile effluents-sources, measurement, discharge consents and simulation: a reviews Journal of Chemical Technology and Biotechnology. 1999; 74 (11): 1009-1018.

[13] Pearce CI, Lloyd JR, Guthrie JT. The removal of colour from textile wastewater using whole bacterial cells: a review. Dyes Pigments. 2003; 58:179-196. 
[14] Ozacar M and Singel A. Adsorption of metal complex dyes from aqueous solutions by pine sawdust. Bioresour. Technol. 2005; 96:791-795.

[15] Baughman GL and Perenich TA. Fate of dyes in aquatic systems: I. Solubility and partitioning of some hydrophobic dyes and related compounds. Environ. Toxico. Chem.1988; 7:183-199.

[16] Olukanni OD, Osuntoki AA, Gbenle GD. Textile effluent biodegradation potentials of textile effluent-adopted and nonadopted bacteria. Appl Environ Microbiol. 2005; 5(20):837-844.

[17] Mahmoud NH. Toxic effects of the synthetic food dye brilliant blue on liver, kidney and tests functions in rats. J Egypt Soc Toxicol. 2006; 34: 77-84.

[18] Wroblewski F and LaDue JS. Serum glutamic-pyruvic transminase in cardiac and hepatic disease. Proc Soc Exp Biol Med. 1956; 91:569-571.

[19] Bergmeyer HU, Bowers GN Jr, Horder M, Moss DW. Provisional recommendations on IFCC methods for the measurement of catalytic concentrations of enzymes. Part 2. IFCC method for aspartate aminotransferase. Clin Chim Acta. 1976; 70(2):F 19-29.
[20] Bergmeyer HU, Horder M. IFCC methods for the measurement of catalytic concentration of enzymes. Part 3 IFCC method for alanine aminotransferase. J Clin Chem Clin Biochem. 1980; 18:521-534.

[21] Doumas BT, Kwok-Cheung PP, Perry BW, Jendrzejczak B, McComb RB, Schaffer R, Hause LL. Candidate reference method for determination of total bilirubin in serum: development and validation. Clin Chem. 1985; 31(11):17791789 .

[22] Jendrassik L, Grof P. Vereinfachte photometrische method zur bestimmung des bilirubins. Biochem Z. 1938; 297: 81-89.

[23] Larsen K. Creatinine assay by a reaction-kinetic principle. Clin Chim Acta 1972; 41: 209-217.

[24] Ibrahim NY, El-Desoky GE, Ramadan ME and El-Gendi SH. Comparative studies on the effect of some natural and synthetic food colorants on blood glucose and liver glycogen as well as glutamic aminotransferase in rats. Menia J Agric Res Rev. 1988, 10:16-59.

[25] Mackenzie KM, Boysea BG, Field WE, Petsel SR, Chappel CL, Emerson JL and Stanley J. Toxicity of carcinogenicity studies of caramel color in F 344 rats and B 6 C 3 F-1 mice. Food Chem Toxicol. 1992; 30(5): 431-443. 